Felsproben des Meeres und Süsswassers aller Länder, und die Polyeistinen-Mergels von Barbados" (with 30 plates). Thus, nearly to the close of his long life, which took place on the 27th June in the year just closed, he showed no relaxation in his activity.

From the year 1839 Ehrenberg was an Ordinary Professor in the Faculty of Medicine. From 1842 he was Secretary of the Physicomathematical Class of the Academy of Sciences, of which he had been a member since 1827. In 1839 king Friedrich Wilhelm III. conferred upon him the great gold medal for Art and Science; and at the same time the Crown Prince gave him a gold medal relating specially to Ehrenberg's discoveries; the Civil Class of the order "Pour le mérite" counted him as one of its members from the time of its establishment by king Friedrich Wilhelm IV.; and foreign honours were not wanting in recognition of his scientific merits.

Quite in the evening of his life he was gratified by the receipt of the large gold medal founded by the Dutch Academy of Sciences at Amsterdam in honour of Leeuwenhoek, the discoverer of the Infusoria, and conferred for the first time unanimously upon Ehrenberg.

\title{
Corals in the Hunterian Museum figured by Ellis and Solander.
}

To the Editors of the Annals and Magazine of Natural History.

Gentlemen.-In rearranging the corals in the Hunterian Museum I recognized the nineteen specimens mentioned in the following list as figured in Ellis and Solander's work. Doubtless more of the Hunterian specimens are figured in that work; but I have only given those which have some characteristic feature admitting of certain identification. Moreover Ellis selected for illustration parts only of some of the bulkier specimens. The list, however, as it stands, will not be without interest to those who desire that the location of type specimens should be known.

Glasgow University, Nov. 1876.

$$
\begin{aligned}
& \text { I am, Gentlemen, } \\
& \text { Yours obediently, } \\
& \text { JoHN Young, M.D. }
\end{aligned}
$$

List of Specimens in Hunterian Museum figured in Ellis and Solander's ' Natural History of Zoophytes.'

1. Pl. 29. Madrepora anthophyllites.

2. Pl. 32. fig. 1 . ?

3. Pl. 35. M. carduus.

4. $\mathrm{Pl}$. 34. M. angulosa.

5. Pl. 38. M. ramea.

6. Pl. 39. M. aspera.

7. Pl. 40. $M$. undata.

8. Pl. 41. figs. 1, 2. M. ampliata.

9. Pl. 43. M. cinerascens.

10. Pl. 45. M. pileus.
11. Pl. 46. fig. 1. Madrepora dadalea.

12, \{ $\mathrm{Pl}$. 47.figs. 4, 5. M. areolata.

13. Pl. 48. fig. 2. M. phrygia.

14. Pl. 50. fig. 2. M. abdita.

15. Pl. 52. M. foliosa.

16. $\{$ Pl. 53. fig. 1. M. annulosa.

figs. 5, 6. M. foveolata.

17. P1. 55. M. rotulosa.

18. $\mathrm{Pl}$. 56. $M$. interstincta.

19. Pl.57. M. muricata. 


\section{$2 \mathrm{BHL}$ Biodiversity Heritage Library}

1877. "Corals in the Hunterian Museum figured by Ellis and Solander." The Annals and magazine of natural history; zoology, botany, and geology 19, 116-116. https://doi.org/10.1080/00222937708682101.

View This Item Online: https://www.biodiversitylibrary.org/item/85173

DOI: https://doi.org/10.1080/00222937708682101

Permalink: https://www.biodiversitylibrary.org/partpdf/64191

\section{Holding Institution}

Smithsonian Libraries

\section{Sponsored by}

Smithsonian

\section{Copyright \& Reuse}

Copyright Status: Public domain. The BHL considers that this work is no longer under copyright protection.

This document was created from content at the Biodiversity Heritage Library, the world's largest open access digital library for biodiversity literature and archives. Visit BHL at https://www.biodiversitylibrary.org. 